\title{
Design and in vitro/in vivo evaluation of sustained- release floating tablets of itopride hydrochloride
}

\author{
This article was published in the following Dove Press journal: \\ Drug Design, Development and Therapy \\ 14 December 2016 \\ Number of times this article has been viewed
}

\author{
Sayed MAhmed' \\ Adel Ahmed Ali² \\ Ahmed MA Ali ${ }^{2,3}$ \\ Omiya A Hassan ${ }^{2,4}$ \\ 'Department of Industrial Pharmacy, \\ Faculty of Pharmacy, Assiut \\ University, Assiut, ${ }^{2}$ Department of \\ Pharmaceutics, Faculty of Pharmacy, \\ Beni-Suef University, Beni-Suef, Egypt; \\ ${ }^{3}$ Department of Pharmaceutics, \\ Faculty of Pharmacy, Taif University, \\ Taif, Kingdom of Saudi Arabia; \\ ${ }^{4}$ Department of Pharmaceutics, \\ Faculty of Pharmacy, Deraya \\ University, El-Minia Gadida, Egypt
}

Purpose: The aim of the present study was to improve the bioavailability of itopride (ITO) and sustain its action by formulating as a floating dosage form.

Materials and methods: Sustained-release floating tablets of ITO hydrochloride $(\mathrm{HCl})$ were prepared by direct compression using different hydrocolloid polymers such as hydroxypropyl methylcellulose and ethylcellulose and/or methacrylic acid polymers Eudragit RSPM and Carbopol 934P. The floating property was achieved using an effervescent mixture of sodium bicarbonate and anhydrous citric acid ( $1: 1 \mathrm{~mol} / \mathrm{mol})$. Hardness, friability, content uniformity, and dissolution rate of the prepared floating tablets were evaluated. The formulation $\mathrm{F}_{10}$ composed of $28.5 \%$ Eudragit RSPM, 3\% $\mathrm{NaHCO}_{3}$, and $7 \%$ citric acid provided sustained drug release.

Results: In vitro results showed sustained release of $\mathrm{F}_{10}$ where the drug release percentage was $96.51 \% \pm 1.75 \%$ after 24 hours $(P=0.031)$. The pharmacokinetic results indicated that the area under the curve $\left(\mathrm{AUC}_{0-\infty}\right)$ of the prepared sustained-release floating tablets at infinity achieved $93.69 \mu \mathrm{g} \cdot \mathrm{h} / \mathrm{mL}$ compared to $49.89 \mu \mathrm{g} \cdot \mathrm{h} / \mathrm{mL}$ for the reference formulation $\left(\right.$ Ganaton $\left.^{\circledR}\right)$ and the relative bioavailability of the sustained-release formulation $\mathrm{F}_{10}$ increased to $187.80 \%(P=0.022)$.

Conclusion: The prepared floating tablets of ITO $\mathrm{HCl}\left(\mathrm{F}_{10}\right)$ could be a promising drug delivery system with sustained-release action and enhanced drug bioavailability.

Keywords: itopride $\mathrm{HCl}$, oral drug delivery, stability study, bioavailability

\section{Introduction}

Itopride (ITO) hydrochloride $(\mathrm{HCl})$ is a prokinetic agent ${ }^{1}$ and has anticholinesterase activity and dopamine $\mathrm{D}_{2}$-receptor antagonistic action. Gastrointestinal motility disorders can be treated using ITO $\mathrm{HCl}$. ITO can activate the motility of the gastrointestinal tract by synergism of its dopamine $\mathrm{D}_{2}$-receptor antagonistic effect and its acetylcholinesterase inhibitory effect. The drug also acts as an antiemetic due to its dopamine $\mathrm{D}_{2}$-receptor antagonistic effect. ${ }^{2}$ The mode of action, which includes each of the acetylcholinesterase inhibitory action and dopamine $\mathrm{D}_{2}$ antagonism, is only for this drug, and its action is different from the mode of action of other prokinetic drugs. ${ }^{2}$

Because the drug can be used for chronic conditions, sustained-release oral dosage forms should increase the compliance of the patient and improve its therapeutic response by decreasing the peak-to-trough variation of ITO $\mathrm{HCl}$ plasma concentration. The only available extended-release ITO per-oral dosage forms are effective in gastric motility disorder treatment over 24 hours. ${ }^{3,4}$

ITO is soluble in water and its solubility is not much affected by the $\mathrm{pH} .{ }^{5}$ Reference ITO is a good choice for formulation as a gastroretentive dosage form because its solubility in the stomach medium is high compared to its solubility in the small intestine medium. ${ }^{6,7}$
Correspondence: Omiya A Hassan Department of Pharmaceutics, Faculty of Pharmacy, Deraya University, 44 El Tayaran Street, PO Box 61768, El-Minia Gadida, Egypt

Tel +20 I0 09332419

Email moniaali33@yahoo.com 
The floating dosage forms have been described by several studies. ${ }^{8} 9$ These systems are formulated to have a bulk density lower than the density of gastric fluid; hence, the buoyancy time of the floating dosage form was prolonged without any effects on the rate of gastric emptying. ${ }^{1,2}$ These systems have important advantages that include achieving a greater and prolonged therapeutic effect and thus reducing the frequency of administration periods, providing a more effective treatment of local stomach disorders, and minimizing both lower tract inactivation of the drug and drug effects on the lower intestinal flora. However, many limitations of the floating dosage forms were reported. They were not applicable for irritant drugs for gastric mucosa, andthey were also not suitable for drugs that have either solubility or stability problems in gastric fluids.

In the present work, the formula that provided good floating and extended-release characteristics was chosen for in vivo evaluation in comparison with a commercial immediaterelease product of ITO $\mathrm{HCl}$. Therefore, this research was aimed at improving the bioavailability of ITO $\mathrm{HCl}$ and reducing the required daily dose of this drug by formulating it as an extended-release tablet formula. An in vivo study was also conducted on rabbits to calculate the pharmacokinetic parameters of the selected floating tablet formula and to estimate the relative bioavailability in comparison to the commercial tablet formula of ITO HCl. A stability study was performed to determine the shelf life of the prepared formula compared to the reference generic product $\left(\right.$ Ganaton $\left.^{\circledR}\right)$.

\section{Materials and methods}

\section{Materials}

ITO $\mathrm{HCl}$ was obtained from Hangzhou Uniwise International Co., Ltd. (Shanghai, China). Hydroxypropyl methylcellulose
(HPMC) 15000 was obtained from Sigma-Aldrich Co. (St Louis, MO, USA). Ethylcellulose (EC) was obtained from EMD Millipore (Billerica, MA, USA). Microcrystalline cellulose (Avicel PH 101) was purchased from FMC BioPolymer International Co. (Philadelphia, PA, USA). Eudragit RSPM was obtained from Rhom Pharma GmbH (Darmstadt, Germany). Sodium bicarbonate and citric acid were supplied from El Gomhoria Co. (Assuit, Egypt). Magnesium stearate was supplied from Alba Chemical Company (Alexandria, Egypt). High-performance liquid chromatography (HPLC)grade methanol was obtained from Sigma-Aldrich Co. Chloroform was obtained from El-Nasr Pharmaceutical Chemicals Company (Cairo, Egypt). Dibasic ammonium phosphate was obtained from BDH Chemicals Ltd. Co. (Poole, England). Commercial immediate-release ITO $\mathrm{HCl}$ tablets were supplied from Abbott Laboratories (Abbott Park, IL, USA). All other chemicals were of analytical grade and used as received.

\section{Preparation of floating tablets}

Floating matrix tablets of ITO $\mathrm{HCl}$ were prepared using direct compression technique by using the following ingredients: HPMC 15000, EC, Eudragit RSPM, magnesium stearate, and sodium bicarbonate. ${ }^{10}$ The composition of the prepared formulations is listed in Table 1. Sodium bicarbonate was added as a gas-generating agent to maintain the buoyancy of the tablets by producing carbon dioxide in the gastric environment. Drug and the polymer (HPMC 15000, EC, and Eudragit RSPM) were mixed well, and magnesium stearate was finally added and mixed by geometrical mixing. A single die punch machine (EK/0; Korsch, Berlin, Germany) fitted with flat-faced punches (12 $\mathrm{mm}$ diameter) was used.

Table I Formulation of ITO HCl floating tablets

\begin{tabular}{|c|c|c|c|c|c|c|c|c|c|}
\hline \multirow{2}{*}{$\begin{array}{l}\text { Formula } \\
\text { ID number }\end{array}$} & \multicolumn{9}{|c|}{ Content (mg) } \\
\hline & ITO & $\begin{array}{l}\text { HPMC } \\
15000\end{array}$ & EC & $\begin{array}{l}\text { Eudragit } \\
\text { RSPM }\end{array}$ & Avicel & $\mathbf{C A}$ & $\mathrm{NaHCO}_{3}$ & $\begin{array}{l}\text { Magnesium } \\
\text { stearate }\end{array}$ & $\begin{array}{l}\text { Total } \\
\text { weight }\end{array}$ \\
\hline $\mathrm{F}_{1}$ & 150 & 100 & 0 & 0 & 60 & 24.35 & 10.65 & 5 & 350 \\
\hline $\mathrm{F}_{2}$ & 150 & 120 & 0 & 0 & 40 & 24.35 & 10.65 & 5 & 350 \\
\hline $\mathrm{F}_{3}$ & 150 & 150 & 0 & 0 & 10 & 24.35 & 10.65 & 5 & 350 \\
\hline $\mathrm{F}_{4}$ & 150 & 0 & 100 & 0 & 60 & 24.35 & 10.65 & 5 & 350 \\
\hline $\mathrm{F}_{5}$ & 150 & 0 & 120 & 0 & 40 & 24.35 & 10.65 & 5 & 350 \\
\hline $\mathrm{F}_{6}$ & 150 & 0 & 150 & 0 & 10 & 24.35 & 10.65 & 5 & 350 \\
\hline $\mathrm{F}_{7}$ & 150 & 0 & 0 & 100 & 60 & 24.35 & 10.65 & 5 & 350 \\
\hline $\mathrm{F}_{8}$ & 150 & 0 & 0 & 120 & 40 & 24.35 & 10.65 & 5 & 350 \\
\hline$F_{9}$ & 150 & 0 & 0 & 150 & 10 & 24.35 & 10.65 & 5 & 350 \\
\hline $\mathrm{F}_{10}$ & 150 & 0 & 50 & 100 & 10 & 24.35 & 10.65 & 5 & 350 \\
\hline
\end{tabular}

Abbreviations: ITO, itopride; $\mathrm{HCl}$, hydrochloride; HPMC, hydroxypropyl methylcellulose; EC, ethylcellulose; CA, citric acid. 


\section{Pharmaceutical evaluation of floating tablet \\ Floating behavior of the tablets}

The buoyancy of the prepared floating tablets was examined by the floating lag time (the time between placing the tablet in the medium and the floating time).

The formulated tablets were placed in a $100 \mathrm{~mL}$ beaker containing $0.1 \mathrm{~N} \mathrm{HCl}$. The time required for the tablets to rise on the surface and then float was calculated as the floating lag time. However, the floating time is taken as the period of time during which the tablet remains floating on the gastric fluid. The buoyancy determination method was explained by Reddy and Murthy. ${ }^{11}$

\section{Resultant weight determination}

To achieve properly principle of the buoyancy retention, a minimal gastric content was needed. However, the floating force $(F)$ of the dosage form should be able to keep the buoyancy of the drug delivery system on the surface of the gastric content.

The determination of density is not enough to predict the floating force evolution of the drug delivery systems because the dry content of the systems reacts or interacts with the gastric secretion to release their drug contents. To determine the floating force, an accurate method for measuring resultant weight (RW) has been reported in the literature. ${ }^{12,13}$

RW of the tablet was calculated as indicated in equation 1 and 2:

$$
\begin{aligned}
& \mathrm{RW}=F_{\text {buoy }}-F_{\text {grav }} \\
& \mathrm{RW}=\left(D_{\mathrm{f}}-D_{\mathrm{s}}\right) g V
\end{aligned}
$$

here, $g$ is the acceleration of gravity, $D_{\mathrm{f}}$ is the fluid density, $D_{\mathrm{s}}$ is the tablet density, $D_{\mathrm{f}}$ is the gastric secretion density, and $V$ is the volume of the tablet.

\section{Solubility study}

The solubility determinations of pure ITO $\mathrm{HCl}$ were performed in a water and acidic medium $(\mathrm{pH} 1.2)$ and a phosphate buffer medium ( $\mathrm{pH}$ 6.8). A sample of $2 \mathrm{~g}$ of ITO $\mathrm{HCl}$ was added to $25 \mathrm{~mL}$ of each aforementioned medium in a glass vial with a cap. The vials were inserted in a shaker incubator and kept at $37^{\circ} \mathrm{C} \pm 0.5^{\circ} \mathrm{C}$ for 24 hours. The samples were filtered and assayed UV spectrophotometrically at $\lambda_{\max } 258 \mathrm{~nm}$.

\section{Determination of hardness}

The formulated tablet was placed between the two anvils of hardness tester (Erweka-type TBT; Erweka GmbH,
Heusenstamm, Germany), and force (in kg) was gradually increased for getting exact reading. The reading was determined referring to the pressure that was required for breaking the tablets. ${ }^{14}$

\section{Friability}

The formulated tablets (20 tablets) were weighed and then placed in the friabilator (Erweka friabilator apparatus; Erweka $\mathrm{GmbH}$ ), and the apparatus was rotated at $25 \mathrm{rpm}$ for 4 minutes. After revolutions, the tablets were dedusted and weighed again. The obtained value should not be $>1 \%$. The friability percent was determined using the following formula: ${ }^{15}$

$$
\% F=\left[1-\left(W_{\mathrm{t}} / W_{\mathrm{i}}\right)\right] \times 100
$$

where $\% F=$ friability percent, $W_{\mathrm{i}}=$ initial weight of the tablet, and $W_{\mathrm{t}}=$ weight of the tablet after revolution.

\section{Drug content}

Five tablets of each formula were triturated. The amount of powder equal to $100 \mathrm{mg}$ of the drug was weighed and placed in a $100 \mathrm{~mL}$ volumetric flask. $\mathrm{HCl}(0.1 \mathrm{~N})$ was added to the powder and the flask was shaken for 5 minutes. In all, $0.1 \mathrm{~N}$ $\mathrm{HCl}$ was added up to $100 \mathrm{~mL}$. The solution was sonicated for 15 minutes and then filtered using a Whatman filter paper. Finally, the solution was diluted with $0.1 \mathrm{~N} \mathrm{HCl}$, and the absorbance of the diluted solution was measured using a spectrophotometer (UV-visible) at $258 \mathrm{~nm}$ against $0.1 \mathrm{~N}$ $\mathrm{HCl}$ blank. ${ }^{16}$

\section{Weight variation}

The formulated tablets (20 tablets) were selected from each batch and individually weighed using an electronic balance. The average weight of the 20 tablets was determined.

\section{In vitro dissolution studies}

In vitro dissolution studies for the prepared floating tablets of ITO $\mathrm{HCl}$ were examined in $0.1 \mathrm{~N} \mathrm{HCl}$ at $37^{\circ} \mathrm{C} \pm 0.5^{\circ} \mathrm{C}$. The dissolution test was carried out for 24 hours, and cumulative drug release was determined for each 1 hour time interval. ${ }^{17}$

The dissolution examination was carried out using USP Dissolution Apparatus II (paddle type; Takao Manufacturing Co. Ltd, Kyoto, Japan) rotating at $75 \mathrm{rpm}$. The dissolution medium was heated to $37^{\circ} \mathrm{C} \pm 1^{\circ} \mathrm{C}$. Aliquots of dissolution medium $(5 \mathrm{~mL})$ were withdrawn at specified time intervals. Then, $5 \mathrm{~mL}$ of freshly prepared acid medium was added to the dissolution medium. Determination of the ITO $\mathrm{HCl}$ was 
carried out spectrophotometrically at $\lambda_{\max } 258 \mathrm{~nm}$, using the same dissolution medium as a blank. All determinations were conducted three times.

\section{Mechanism of drug release}

The mechanism of drug release from matrices can be determined by treating the dissolution value of each formula with different kinetic release models. ${ }^{18}$ The drug release values were plotted according to zero-order, first-order, and Higuchi diffusion models.

\section{In vivo evaluation of a selected floating formula by comparative bioavailability study}

Treatment protocol and sample analysis

The chosen floating formula containing $150 \mathrm{mg}$ of ITO was compared with the commercial immediate-release ITO $\mathrm{HCl}$ tablets. The study was achieved using three groups of New Zealand rabbits $(2.5 \mathrm{~kg})$, each group consisting of three rabbits. Group I (control group) was starved and only water was allowed. Group II was administered the floating tablet formula $\mathrm{F}_{10}$. Group III was administered the commercial six tablets. The rabbit groups II and III were starved overnight before the administration of the drug and continued fasting until 4 hours postdose. Each group was given a drug dose of $15 \mathrm{mg} / \mathrm{kg}$ from the tested preparations $\left(\mathrm{F}_{10}\right)$ and the commercial tablets. The study was performed as single-dose crossover design, with 7 days washout period. Blood samples $(1 \mathrm{~mL})$ were taken from the marginal ear vein and were transferred to tubes containing heparin at time intervals $0,0.5,1,2,4,6,8,12,18$, and 24 hours after drug administration. Plasma was directly separated using a centrifuge and was kept at $-20^{\circ} \mathrm{C}$ until used for analysis. Before the administration of the drug, samples of the blood were collected and plain plasma was separated by centrifugation and used for the construction of the calibration curve. All experiments were performed following relevant international regulations as per the Guide for the Care and Use of Laboratory Animals and were approved by the Assiut University Ethical Experimentation Committee of Faculty of Medicine.

The plasma samples were treated with $10 \%$ perchloric acid to precipitate the protein, followed by centrifugation at 4,000 rpm for 15 minutes. Analyses of ITO $\mathrm{HCl}$ were conducted using an HPLC with fluorescence detection. Levofloxacin was used as an internal standard. A reversed phase Hypersil BDS C18 $(250 \times 4.6$ mm, $5 \mathrm{~m})$ column was used. An isocratic degassed mobile phase was prepared using $0.2 \mathrm{~mol} / \mathrm{L}$ ammonium acetate-methanol (15:85, v/v), and the flowing rate was $1.1 \mathrm{~mL} / \mathrm{min}$. The wavelengths of excitation and emission during the analysis were at $304 \mathrm{~nm}$ and $344 \mathrm{~nm}$, respectively. From plasma concentrations of the $\mathrm{ITO} \mathrm{HCl}$, the pharmacokinetic parameters were calculated. The determination of the drug was carried out in triplicate.

\section{Calculation and statistical treatment of pharmacokinetic parameters}

The pharmacokinetic parameters were determined from the data of plasma level obtained from the individual rabbits and presented as mean \pm standard deviation (SD). From the data of plasma concentration, the maximum plasma concentration $\left(C_{\max }, \mu \mathrm{g} / \mathrm{mL}\right)$ and the corresponding time $\left(\mathrm{T}_{\max }\right.$, hour) were directly obtained for the two treatments in each individual rabbit. A plot of the mean plasma concentration versus time was constructed for each treatment. The area under the curve from time 0 to 24 hours $\left(\mathrm{AUC}_{0-24} \mu \mathrm{g} \cdot \mathrm{h} / \mathrm{mL}\right.$ ) was obtained by applying the trapezoidal rule. Accordingly, the area under the curve from time 0 hour to infinity $\left(\mathrm{AUC}_{0-\infty}\right)$ was determined by adding the area under the tail to $\mathrm{AUC}_{0-24 \text { hour }}$. The area under the tail was calculated by dividing the last determined concentration by the elimination rate constant obtained by linear regression of the elimination phase of the plasma concentration versus time curve. The mean residence time (MRT; hour), which is a noncompartmental pharmacokinetic parameter, was determined using a suitable equation. ${ }^{19}$ After the estimation of the area under the first-moment curve $\left(\mathrm{AUC}_{0-\infty}, \mu \mathrm{g} \cdot \mathrm{h} / \mathrm{mL}\right)$, the relative bioavailability $\left(F_{\mathrm{R}}\right)$ of the examined formula compared with the commercial product was calculated as follows:

$$
F_{\mathrm{R}}(\%)=\frac{\mathrm{AUC}_{0-24 \text { hours }}(\text { tested formula })}{\mathrm{AUC}_{0-24 \text { hours }}(\text { commercial product })} \times 100
$$

The significance of the difference between the two treatments was evaluated by one-way analysis of variance using a statistical computer package (SPSS Version 13.0; SPSS Inc., Chicago, IL, USA). Differences were considered significant at $P<0.05$.

\section{Stability study \\ Effect of aging (shelf storage)}

Samples of the selected formulae of ITO $\mathrm{HCl}$ tablets, which gave the most sustaining in vitro drug release, were stored in amber glass bottles and kept at room temperature for 6 months. The selected formulae of the prepared tablets were tested for their drug content, release characteristics, and physical properties.

\section{Accelerated stability testing}

Samples from the selected tablets were stored in amber-colored glass bottles in closed desiccators containing 
saturated solution of sodium chloride to attain $75 \%$ relative humidity $(\mathrm{RH})$. The desiccators were kept at temperatures of $30^{\circ} \mathrm{C}, 40^{\circ} \mathrm{C}$, and $50^{\circ} \mathrm{C} \pm 2.0^{\circ} \mathrm{C}$ in thermostatically controlled hot air ovens for 6 months. The samples from each of the selected formulae were withdrawn after time intervals of 0.5 , $1,2,3,4,5$, and 6 months. The drug content was determined using the HPLC assay method.

The mobile phase consisted of filtered, degassed mixture of HPLC-grade methanol and chloroform 9:1 v/v pumped at a flow rate of $1.5 \mathrm{~mL} / \mathrm{min}$. The UV detector was adjusted at $258 \mathrm{~nm}$, and the element peaks were investigated using peak height ratio. All analyses were performed at room temperature.

\section{Determination of drug content in the stored tablets}

Drug content in the stored tablets was determined using the HPLC method. At the specified time intervals, three randomly selected tablets were finally powdered. An accurately weighed amount of powder equivalent to $150 \mathrm{mg}$ of ITO $\mathrm{HCl}$ was mixed with HPLC-grade methanol in a $100 \mathrm{~mL}$ volumetric flask and sonicated for 10 minutes. The solution was filtered, and $1 \mathrm{~mL}$ of the filtrate was transferred to a $25 \mathrm{~mL}$ volumetric flask. In all, $5 \mathrm{~mL}$ of the internal standard stock solution was pipetted into each volumetric flask and the volume was completed in the mobile phase. The obtained clear solutions were filtered through a $0.45 \mu \mathrm{m}$ disk filter, degassed, and then $20 \mu \mathrm{L}$ of solutions were injected onto the HPLC column. ITO $\mathrm{HCl}$ concentration in each sample was determined utilizing the constructed calibration curve.

\section{Statistical analysis}

SPSS Version 18 software (SPSS Inc.) was used to analyze the data. All the trials were carried out in triplicate, and the results were expressed as mean \pm SD. The data for various formulations were statistically analyzed using one-way analysis of variance. $P<0.05$ was considered to be statistically significant. The differences were evaluated for statistical significance using the Student's $t$-test.

\section{Results}

\section{Solubility study}

Solubility of ITO HCl in water, acidic medium ( $\mathrm{pH} 1.2)$, and alkaline solution ( $\mathrm{pH} 7.4$ ) was $48.4 \mathrm{mg} / \mathrm{mL}, 50.5 \mathrm{mg} / \mathrm{mL}$, and $47.6 \mathrm{mg} / \mathrm{mL}$, respectively. Although the solubility of the drug in the acidic medium was the highest, it was not much affected by the change in the $\mathrm{pH}$. These findings are in agreement with those reported by Satapathy et al. ${ }^{5}$

\section{Evaluation of the prepared ITO $\mathrm{HCl}$ tablets}

Formulations of floating ITO $\mathrm{HCl}$ tablets prepared were evaluated for different parameters, eg, thickness, hardness, friability, percent of weight variation, and percent of the drug content (Table 2). All the formulation of tablets showed uniform thickness and diameter. Concerning the test of weight variation, the pharmacopeial limit of the percentage deviation for the prepared ITO $\mathrm{HCl}$ floating tablets having a weight of $350 \mathrm{mg}$ was $\pm 5 \%$.

The mean percentage deviation for each of the prepared ITO $\mathrm{HCl}$ floating tablet formulation was found to lie within this limit, and so all ITO $\mathrm{HCl}$ floating tablet formulations passed the uniformity test of weight according to official requirements. ${ }^{20}$ The test of drug content was found to be uniform at different tablet formulations, and the percentage of the drug content was $>98 \%$, w/w. The hardness of all batches was found to be between $4.5 \mathrm{~kg} / \mathrm{cm}^{2}$ and $7.0 \mathrm{~kg} / \mathrm{cm}^{2}$. The friability percent for all the formulations of tablets of $<1 \%$ indicated that the friability percent is within the

Table 2 Properties of the prepared tablet

\begin{tabular}{|c|c|c|c|c|c|}
\hline $\begin{array}{l}\text { Formula } \\
\text { ID number }\end{array}$ & $\begin{array}{l}\text { Mean weight } \\
(\mathrm{mg}) \pm \mathrm{SD}, \mathrm{n}=\mathbf{2 0}\end{array}$ & $\begin{array}{l}\text { Mean thickness } \\
(\mathrm{mm}) \pm \mathrm{SD}, \mathrm{n}=\mathbf{2 0}\end{array}$ & $\begin{array}{l}\text { Friability } \\
\text { (\% loss), } n=10\end{array}$ & $\begin{array}{l}\text { Mean hardness } \\
(\mathrm{kg}) \pm \mathrm{SD}, \mathrm{n}=10\end{array}$ & $\begin{array}{l}\text { Drug content } \\
(\mathrm{mg} \%) \pm \mathrm{SD}, \mathrm{n}=10\end{array}$ \\
\hline $\mathrm{F}_{1}$ & $351.7 \pm 1.7$ & $3.6 \pm 0.029$ & 0.57 & $7.0 \pm 0.77$ & $96.92 \pm 2.42$ \\
\hline $\mathrm{F}_{2}$ & $350.8 \pm 2.4$ & $3.6 \pm 0.035$ & 0.68 & $7.0 \pm 0.62$ & $98.4 I \pm 2.85$ \\
\hline $\mathrm{F}_{3}$ & $352.3 \pm 1.9$ & $3.6 \pm 0.017$ & 0.73 & $6.8 \pm 0.77$ & $100.12 \pm 1.97$ \\
\hline $\mathrm{F}_{4}$ & $350.6 \pm 2.3$ & $3.6 \pm 0.011$ & 0.95 & $4.7 \pm 0.69$ & $97.15 \pm 2.78$ \\
\hline $\mathrm{F}_{5}$ & $350.5 \pm 2.4$ & $3.6 \pm 0.004$ & 0.94 & $4.5 \pm 1.04$ & $100.44 \pm 2.85$ \\
\hline $\mathrm{F}_{6}$ & $350.8 \pm 2.8$ & $3.6 \pm 0.021$ & 0.63 & $5.7 \pm 0.85$ & $100.71 \pm 3.05$ \\
\hline $\mathrm{F}_{7}$ & $350.7 \pm 2.7$ & $3.5 \pm 0.024$ & 0.35 & $7.0 \pm 0.65$ & $99.58 \pm 1.89$ \\
\hline $\mathrm{F}_{8}$ & $351.6 \pm 2.3$ & $3.6 \pm 0.009$ & 0.45 & $6.7 \pm 0.87$ & $96.12 \pm 1.75$ \\
\hline $\mathrm{F}_{9}$ & $350.5 \pm 3.2$ & $3.6 \pm 0.001$ & 0.54 & $7.0 \pm 0.67$ & $100.81 \pm 2.24$ \\
\hline$F_{10}$ & $350.1 \pm 1.7$ & $3.6 \pm 0.009$ & 0.87 & $7.5 \pm 1.67$ & $100.06 \pm 1.19$ \\
\hline
\end{tabular}

Abbreviation: SD, standard deviation. 
Table 3 Floating properties of ITO $\mathrm{HCl}$ floating tablets

\begin{tabular}{llll}
\hline $\begin{array}{l}\text { Formula } \\
\text { ID number }\end{array}$ & $\begin{array}{l}\text { Lag time } \\
(\mathbf{m i n})\end{array}$ & $\begin{array}{l}\text { Floating } \\
\text { time }(\mathbf{h})\end{array}$ & $\begin{array}{l}\text { Floating } \\
\text { force } \pm \text { SD } \\
\text { (dyne) }\end{array}$ \\
\hline $\mathrm{F}_{1}$ & 2.20 & $>20$ & $+9.5 \pm 0.92$ \\
$\mathrm{~F}_{2}$ & 4.38 & $>20$ & $+8.3 \pm 0.65$ \\
$\mathrm{~F}_{3}$ & 6.20 & $>18$ & $+8.8 \pm 0.78$ \\
$\mathrm{~F}_{4}$ & No floating occurs & No floating occurs & $-1.8 \pm 0.04$ \\
$\mathrm{~F}_{5}$ & No floating occurs & No floating occurs & $-2.3 \pm 0.08$ \\
$\mathrm{~F}_{6}$ & No floating occurs & No floating occurs & $-1.6 \pm 0.11$ \\
$\mathrm{~F}_{7}$ & 3.50 & $>20$ & $+10.3 \pm 0.97$ \\
$\mathrm{~F}_{8}$ & 4.12 & $>20$ & $+9.7 \pm 0.85$ \\
$\mathrm{~F}_{9}$ & 5.10 & $>16$ & $+8.4 \pm 0.67$ \\
$\mathrm{~F}_{10}$ & 20 & $>12$ & $+7.9 \pm 0.59$ \\
\hline
\end{tabular}

Abbreviations: ITO, itopride; $\mathrm{HCl}$, hydrochloride; min, minutes; h, hours; $\mathrm{SD}$, standard deviation

official limits. Finally, it could be concluded that each of the tablet formulations had acceptable pharmacopeial properties and complied with the specifications for hardness, friability, weight variation, and drug content.
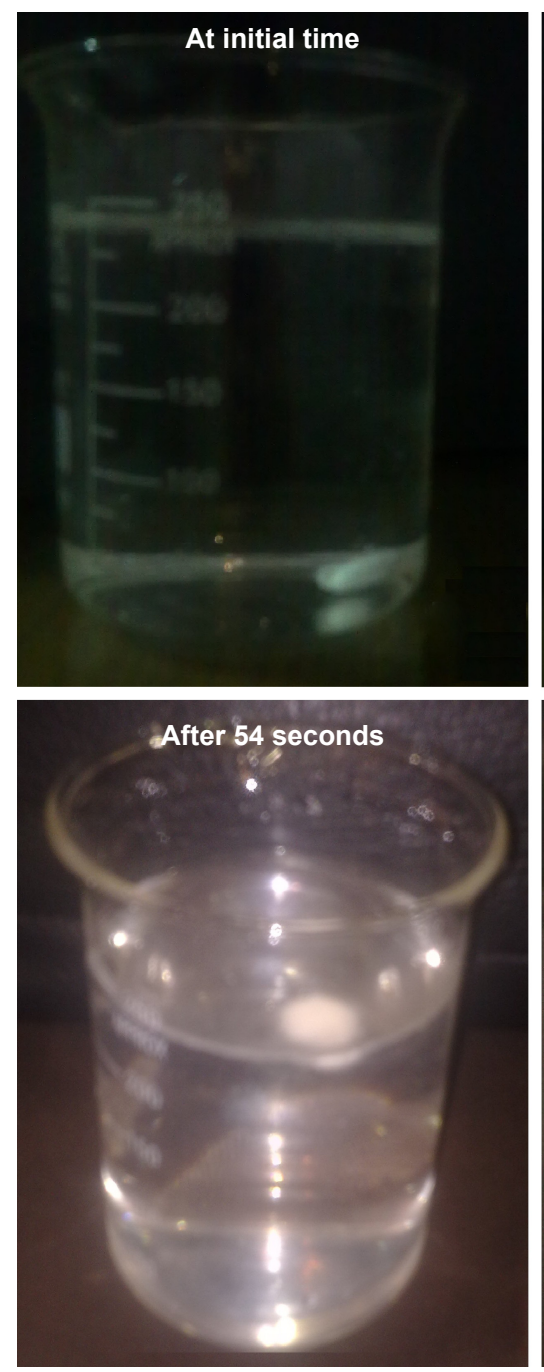
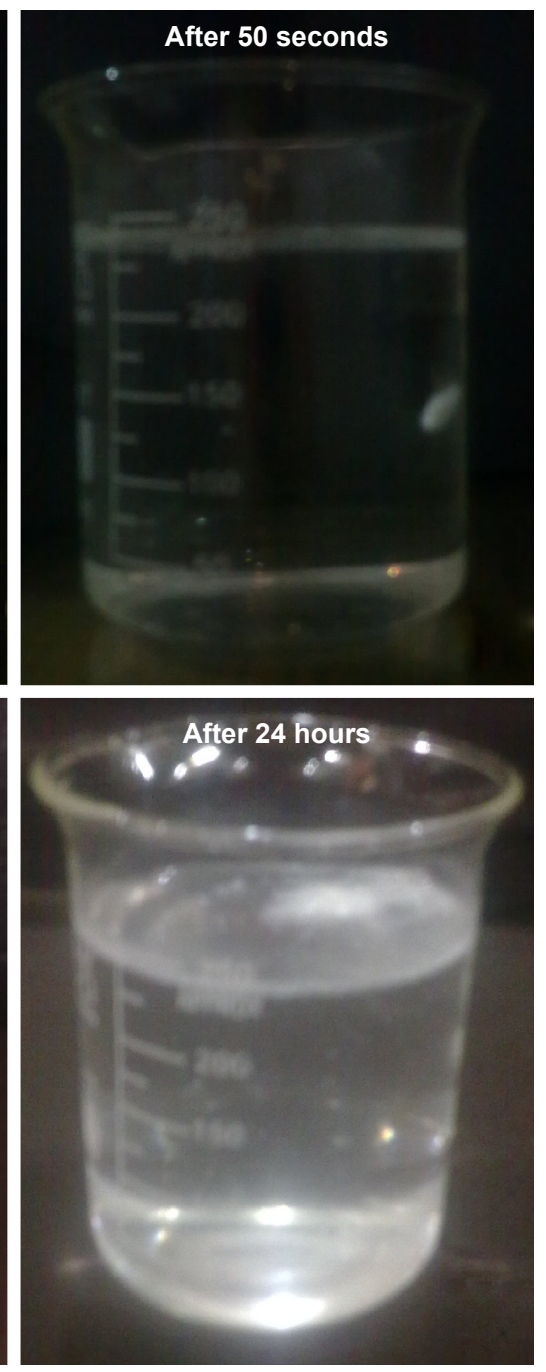

\section{In vitro buoyancy study}

The floating results are shown in Table 3. Sodium bicarbonate generates $\mathrm{CO}_{2}$ in the dissolution medium $(0.1 \mathrm{~N} \mathrm{HCl})$, and the tablet becomes buoyant, as shown in Figure $1 .{ }^{21}$ Thus, sodium bicarbonate was essential to achieve optimum in vitro buoyancy (ie, floating lag time of 3-6 minutes and floating duration of 24 hours). A further increase in sodium bicarbonate concentration does not show any significant effect on the floating behavior. ${ }^{22}$ The floating force was determined as shown in Table 3. Formulae $\mathrm{F}_{4}, \mathrm{~F}_{5}$, and $\mathrm{F}_{6}$ have negative values. However, the other formulae have positive values.

\section{In vitro drug release study}

In vitro release of ITO $\mathrm{HCl}$ from different formulations is shown in Figure 2. Formulations $\mathrm{F}_{1}, \mathrm{~F}_{2}$, and $\mathrm{F}_{3}$ showed $97.33 \% \pm 2.11 \%, 99.57 \% \pm 2.42 \%$, and $99.05 \% \pm 3.04 \%$ drug release at the end of 6,8 , and 12 hours, respectively. Formulations $\mathrm{F}_{4}, \mathrm{~F}_{5}$, and $\mathrm{F}_{6}$ showed drug release of 

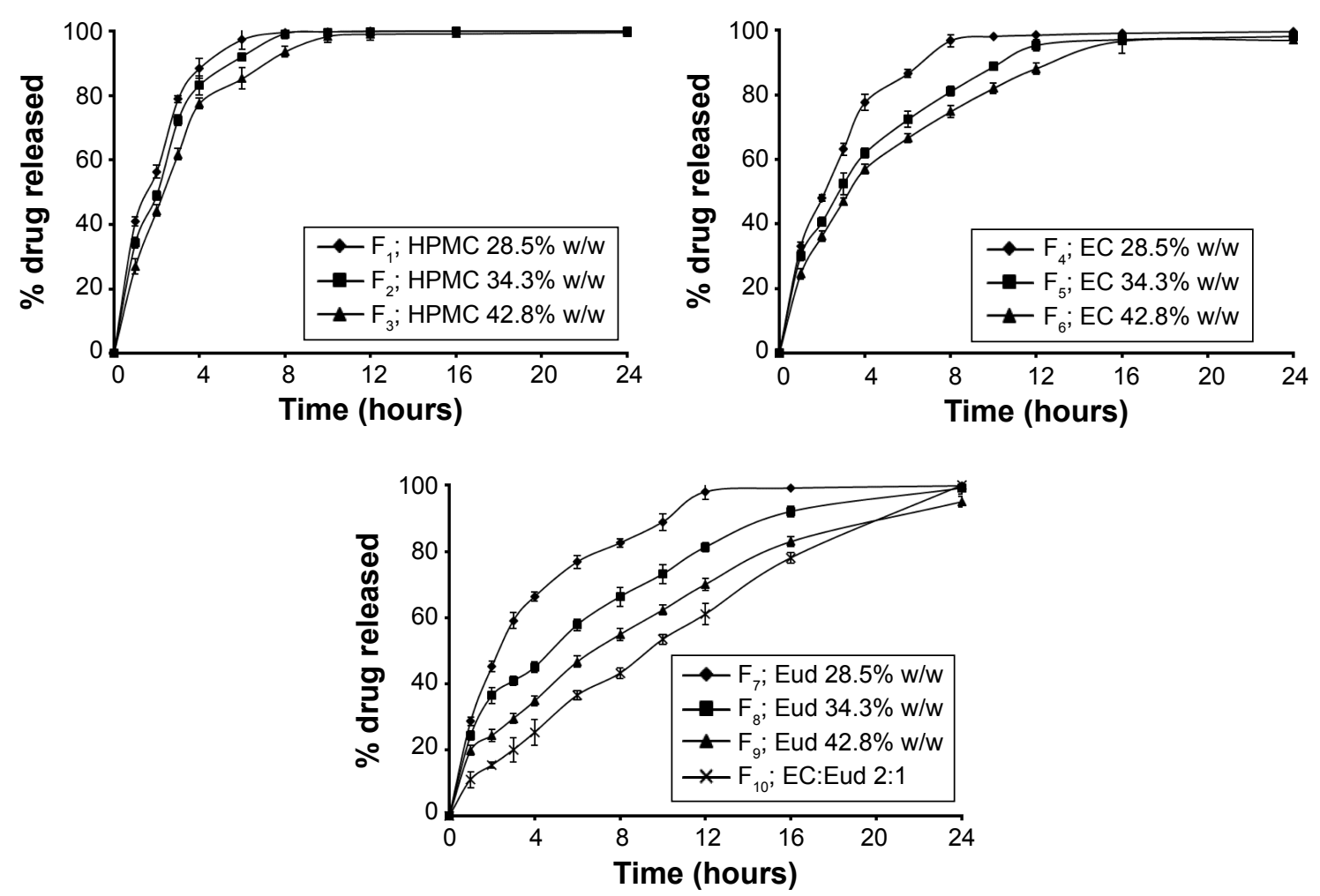

Figure 2 Dissolution profiles of ITO $\mathrm{HCl}$ floating tablets $\mathrm{F}_{1}$ to $\mathrm{F}_{10}$.

Note: Each value represents an average of three determinations (mean $\pm S D, n=3$ ).

Abbreviations: ITO, itopride; $\mathrm{HCl}$, hydrochloride; SD, standard deviation; HPMC, hydroxypropyl methylcellulose; EC, ethylcellulose; Eud, eudragit.

$96.81 \% \pm 2.92 \%, 95.44 \% \pm 1.07 \%$, and $96.73 \% \pm 2.34 \%$ at 8,12 , and 16 hours, respectively. Formulations $\mathrm{F}_{7}, \mathrm{~F}_{8}, \mathrm{~F}_{9}$, and $\mathrm{F}_{10}$ showed $98.01 \% \pm 2.45 \%, 99.07 \% \pm 2.42 \%, 95.06 \% \pm 1.71 \%$, and $96.51 \% \pm 2.91 \%$ drug release at 12,24 , and 24 hours, respectively. $\mathrm{F}_{10}$ was selected as the optimized formulation because it gives sustained release of ITO $\mathrm{HCl}$ over a period of 24 hours up to $96.51 \% \pm 1.75 \%$.

In vitro release data were subjected to various kinetic models to predict the best drug release kinetic mechanism, as shown in Table 4. The kinetic models used were zero-order, first-order, and Higuchi diffusion models. Higuchi diffusion model was fit for the formulations.

\section{Comparative bioavailability of ITO}

The plasma concentration change in ITO with time after oral administration of the reference standard and the prepared floating tablet to rabbits was represented, as shown in Figure 3.

Table 4 Kinetic treatment of the dissolution data for ITO HCl floating tablets

\begin{tabular}{|c|c|c|c|c|c|c|c|c|c|}
\hline \multirow{2}{*}{$\begin{array}{l}\text { Formula } \\
\text { ID number }\end{array}$} & \multicolumn{3}{|c|}{ Zero-order } & \multicolumn{3}{|c|}{ First-order } & \multicolumn{3}{|c|}{ Higuchi diffusion model } \\
\hline & $r$ & $\kappa_{0}$ & Intercept & $r$ & $\kappa_{1}$ & Intercept & $r$ & $K_{\mathrm{h}}$ & Intercept \\
\hline $\mathrm{F}_{1}$ & 0.9292 & 15.5467 & 18.8554 & -0.9924 & -0.2612 & 2.0678 & 0.9926 & 41.7801 & 0.4592 \\
\hline $\mathrm{F}_{2}$ & 0.9499 & II.6297 & 21.6025 & -0.9559 & -0.2720 & 2.1800 & 0.9876 & 37.3064 & 0.5916 \\
\hline $\mathrm{F}_{3}$ & 0.8965 & 7.52021 & 26.7700 & -0.9930 & -0.1722 & 2.0696 & 0.9776 & 30.8758 & 3.2814 \\
\hline $\mathrm{F}_{4}$ & 0.9351 & II.1787 & 19.5760 & -0.9947 & -0.1472 & 1.9902 & 0.9957 & 35.4938 & 0.0230 \\
\hline $\mathrm{F}_{5}$ & 0.9379 & 9.18904 & 16.8818 & -0.9915 & -0.0908 & 1.9615 & 0.9986 & 30.6651 & -0.6809 \\
\hline $\mathrm{F}_{6}$ & 0.9411 & 7.42439 & 17.0139 & -0.9917 & -0.0787 & 1.9701 & 0.9949 & 24.9661 & $2.297 \mid$ \\
\hline $\mathrm{F}_{7}$ & 0.9460 & 6.91069 & 25.3009 & -0.9903 & -0.1054 & 1.9636 & 0.9920 & 28.1457 & 4.1735 \\
\hline $\mathrm{F}_{8}$ & 0.9519 & $5.088 \mid 4$ & 20.1645 & -0.9889 & -0.0617 & 1.9780 & 0.9986 & 22.9854 & 1.2258 \\
\hline $\mathrm{F}_{9}$ & 0.9665 & 6.19359 & 8.78054 & -0.9934 & -0.0442 & 1.9849 & 0.9953 & 20.8059 & -3.3245 \\
\hline$F_{10}$ & 0.9846 & 4.29567 & 4.68339 & -0.9780 & -0.0318 & 2.0137 & 0.9875 & 17.7194 & -8.0137 \\
\hline
\end{tabular}

Notes: Values shown in bold indicate a high value of correlation coefficient for each formula; $K_{0}=$ degradation rate constant for zero order; $K_{1}=$ degradation rate constant for first order; $K_{h}=$ degradation rate constant for Higuchi model.

Abbreviations: ITO, itopride; $\mathrm{HCl}$, hydrochloride. 


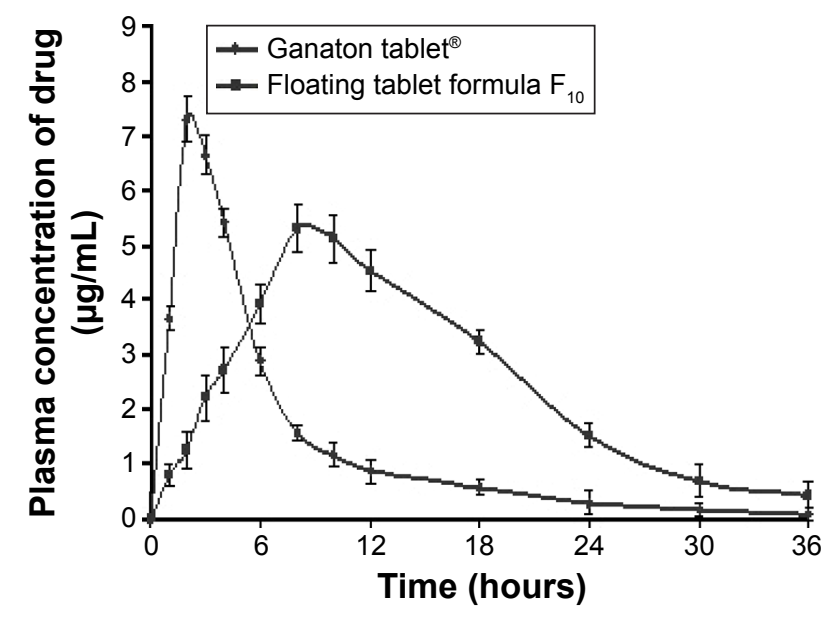

Figure 3 Plasma concentrations of ITO $\mathrm{HCl}$ after oral administration of the commercial tablets and the prepared ITO $\mathrm{HCl}$ sustained-release tablet formula $\mathrm{F}_{10}$. Abbreviations: ITO, itopride; $\mathrm{HCl}$, hydrochloride.

Table 5 shows the pharmacokinetic parameters with \pm SD generated from the individual data analysis. ${ }^{23}$ The maximum concentration $C_{\max }$ of the prepared floating tablets $\left(\mathrm{F}_{10}\right)$ was found to be $5.31 \mu \mathrm{g} / \mathrm{mL}$, and the corresponding $\mathrm{T}_{\text {max }}$ value was 8 hours. It was noted that the floating tablets exhibited delayed $\mathrm{T}_{\max }$.

The $t_{1 / 2}$ value was found to be 1.712 hours for the floating ITO HCL tablet formula. The value of the MRT, which is the noncompartmental analog of $t_{1 / 2}$, was also parallel to that of $t_{1 / 2}$. The examined tablet formula showed higher MRT (15.186 hours). $\mathrm{AUC}_{0-\infty}=93.698 \mu \mathrm{g} \cdot \mathrm{h} / \mathrm{mL}$ for the

Table 5 Pharmacokinetic parameters of ITO HCl following oral administration of the prepared ITO $\mathrm{HCl}$ sustained-release tablets formula $F_{10}$ in comparison with the commercial immediate-release tablets, the commercial tablets

\begin{tabular}{llll}
\hline $\begin{array}{l}\text { Pharmacokinetic } \\
\text { parameter }\end{array}$ & $\begin{array}{l}\text { Commercial } \\
\text { tablets }\end{array}$ & $\begin{array}{l}\text { Formula } \\
\left(\mathbf{F}_{10}\right)\end{array}$ & Significance \\
\hline $\mathrm{T}_{\max }(\mathrm{h})$ & 2 & 8 & $\mathrm{~S}$ \\
$\mathrm{C}_{\max }(\mu \mathrm{g} / \mathrm{mL})$ & 7.299 & 5.310 & $\mathrm{~S}$ \\
$\mathrm{~K}_{\text {abs }}\left(\mathrm{h}^{-1}\right)$ & 0.705 & 0.404 & $\mathrm{~S}$ \\
$\mathrm{t}_{(1 / 2) \mathrm{ab}}(\mathrm{h})$ & 0.982 & 1.712 & $\mathrm{~S}$ \\
$K_{\mathrm{el}}\left(\mathrm{h}^{-1}\right)$ & 0.107 & 0.098 & $\mathrm{NS}$ \\
$\mathrm{t}_{(1 / 2) \text { el }}(\mathrm{h})$ & 6.485 & 7.014 & $\mathrm{NS}$ \\
$V_{\mathrm{d}}(\mathrm{L})$ & 1.016 & 1.069 & $\mathrm{~S}$ \\
$\mathrm{AUC}_{0-24}(\mu \mathrm{g} \cdot \mathrm{h} / \mathrm{mL})$ & 47.052 & 89.356 & $\mathrm{~S}$ \\
$\mathrm{AUC}_{0-\infty}(\mu \mathrm{g} \cdot \mathrm{h} / \mathrm{mL})$ & 49.894 & 93.698 & $\mathrm{~S}$ \\
$\mathrm{AUMC}_{0-24 \mathrm{~h}}\left(\mu \mathrm{g} \cdot \mathrm{h}^{2} / \mathrm{mL}\right)$ & 340.065 & $1,222.668$ & $\mathrm{~S}$ \\
$\mathrm{AUMCC}_{(0-\infty)}\left(\mu \mathrm{g} \cdot \mathrm{h}^{2} / \mathrm{mL}\right)$ & 436.324 & $1,422.935$ & $\mathrm{~S}$ \\
$\mathrm{MRT}(\mathrm{h})$ & 8.745 & 15.186 & $\mathrm{~S}$ \\
$\mathrm{Cl}_{\mathrm{T}}(\mathrm{mL} / \mathrm{min})$ & 5.010 & 2.668 & $\mathrm{~S}$ \\
$\mathrm{~F}_{\mathrm{R}}(\%)$ & $\mathrm{NA}$ & 189.910 & $\mathrm{NA}$ \\
\hline
\end{tabular}

Abbreviations: ITO, itopride; $\mathrm{HCl}$, hydrochloride; $\mathrm{T}_{\text {max }}$, time for maximum absorption; $C_{\max }$, maximum (or peak) serum concentration; $\mathrm{K}_{\text {abs }}$, absorption rate constant; $t_{1 / 2}$, half life time of the absorption; $K_{\mathrm{el}}$, elimination rate constant; $V_{\mathrm{d}}$, volume of distribution; $S$, significant; NS, not significant; AUC, area under the curve; AUMC, area under the first moment curve; MRT, mean residence time; $\mathrm{Cl}_{\mathrm{T}}$, total clearance; $F_{R}$, relative (or comparative) bioavailability; NA, not applicable.
Table 6 Physical properties of the aged batches of floating tablets after shelf storage for 6 months

\begin{tabular}{ll}
\hline Properties & Formula $\mathbf{F}_{10}$ \\
\hline Color change & No changes \\
Mean weight $(\mathrm{mg})$ & $350.0 \mathrm{I}$ \\
Mean thickness $(\mathrm{mm})$ & 3.6 \\
Friability $(\%$ loss) & $0.8 \mathrm{I}$ \\
Mean hardness $(\mathrm{kg})$ & 8.7 \\
Drug content $(\mathrm{mg} \%)$ & 99.42 \\
\hline
\end{tabular}

prepared floating formula; the relative bioavailability was $189.910 \%$. ITO is considered as an example of drugs with high pharmacokinetic variability. The maximum relative standard deviation was $2.91 \%$. The floating tablet showed more sustained-release characteristics.

\section{Stability study}

\section{Effect of aging (shelf storage)}

The changes in the physical properties of the selected formulae of ITO $\mathrm{HCl}$ tablets stored at ambient conditions $\left(30^{\circ} \mathrm{C}\right.$, $40^{\circ} \mathrm{C}$, and $50^{\circ} \mathrm{C} \pm 1{ }^{\circ} \mathrm{C}$ and $75 \% \mathrm{RH}$ ) for 6 months were measured (Table 6). The results revealed that no change in the color of the tablets has occurred during the storage period. Tablet formulae show good physical stability with respect to hardness, friability, and tablet dimensions (diameter and thickness). The drug content in the aged formulae of tablets was not changed significantly $(P<0.05)$ as that of the corresponding freshly prepared formulae. This indicates chemical stability of the active ingredient in the tested formulae.

It was found that the release rate of ITO $\mathrm{HCl}$ from the aged tablets was slightly decreased in comparison with the corresponding freshly prepared dosage form as shown in Figure 4.

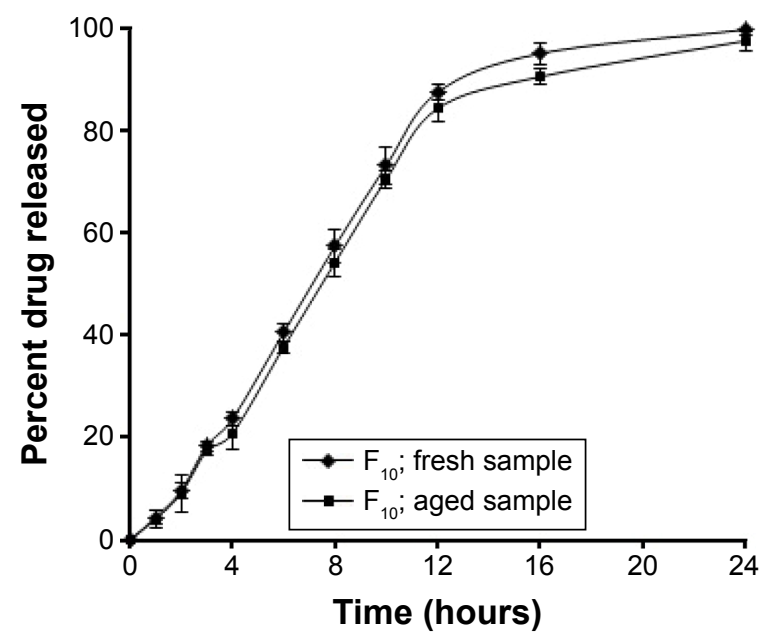

Figure 4 Effect of aging on the release of ITO $\mathrm{HCl}$ from floating tablet formula $\mathrm{F}_{10}$. Abbreviations: ITO, itopride; $\mathrm{HCl}$, hydrochloride. 
Table 7 ITO HCl content in the selected floating tablets stored for 6 months at different temperatures $\left(30^{\circ} \mathrm{C}, 40^{\circ} \mathrm{C}\right.$, and $\left.50^{\circ} \mathrm{C}\right)$ and at $75 \% \mathrm{RH}$

\begin{tabular}{|c|c|c|c|}
\hline \multirow{2}{*}{$\begin{array}{l}\text { Storage time } \\
\text { (months) }\end{array}$} & \multicolumn{3}{|c|}{ Drug remaining (\%) } \\
\hline & At $30^{\circ} \mathrm{C}$ & At $40^{\circ} \mathrm{C}$ & At $50^{\circ} \mathrm{C}$ \\
\hline 0 & 100.15 & 100.08 & 100.05 \\
\hline I & 100.04 & 100.02 & 100.01 \\
\hline 2 & 99.97 & 99.63 & 99.44 \\
\hline 3 & 99.62 & 99.21 & 98.82 \\
\hline 4 & 99.29 & 98.81 & 98.25 \\
\hline 5 & 99.01 & 98.48 & 98.03 \\
\hline 6 & 98.82 & 98.33 & 97.63 \\
\hline \multicolumn{4}{|l|}{ Zero-order } \\
\hline$r$ & -0.991 & -0.983 & -0.986 \\
\hline$A$ & $100.7 \mid$ & 100.63 & 100.59 \\
\hline B & -0.3367 & -0.4235 & -0.52893 \\
\hline \multicolumn{4}{|l|}{ First-order } \\
\hline$r$ & -0.992 & -0.984 & -0.987 \\
\hline$A$ & 2.00308 & 2.002749 & 2.00258 \\
\hline B & $-14.7 \times 10^{-4}$ & $-18.5 \times 10^{-4}$ & $-23.2 \times 10^{-4}$ \\
\hline Mechanism of degradation & First-order & First-order & First-order \\
\hline$K_{1}\left(\right.$ day $\left.^{-1}\right)$ & $11.25 \times 10^{-5}$ & $14.20 \times 10^{-5}$ & $17.80 \times 10^{-5}$ \\
\hline
\end{tabular}

However, there was a decrease in the release rate of the drug from the aged formulae; this was not seen as a practically effective difference in the drug release because it is a common practice to report the release results of sustained-release products in terms of a range than as a single point.

Accelerated stability testing of ITO $\mathrm{HCl}$ in the selected formulae.

Table 7 shows the remaining ITO $\mathrm{HCl}$ content in the selected floating tablets formula $\mathrm{F}_{10}$ after storage for 6 months

Table 8 First-order degradation kinetics parameters of ITO $\mathrm{HCl}$ in different formulae after storage for 6 months at different temperatures

\begin{tabular}{ll}
\hline $\begin{array}{l}\text { Reciprocal absolute } \\
\text { temperature }(I / T)\end{array}$ & $\begin{array}{l}\text { Log first-order } \\
\text { degradation rate }(K)\end{array}$ \\
\hline $\mathrm{I} / 323^{*}$ & -3.749 \\
$\mathrm{I} / 3 \mathrm{I}^{*}$ & -3.847 \\
$\mathrm{I} / 303^{*}$ & -3.948 \\
$A$ & 0.00117092 \\
$B$ & -0.321150 \\
$r$ & -0.999 \\
Predicted $K_{25}\left(\right.$ day $\left.^{-1}\right)$ & $9.32346 \times 10^{-5}$ \\
Shelf life (days) $=0.105 / K_{25}$ & $1,126.190885$ \\
Shelf life (years) & 3.077024277 \\
\hline
\end{tabular}

Notes: $r$ is the correlation coefficient, $A$ the intercept, and $B$ the slope of the corresponding equation. $K$ is the first-order degradation rate constant.

Abbreviations: ITO, itopride; $\mathrm{HCl}$, hydrochloride; T, absolute temperature; $I / T$, inverse absolute temperature. at different temperatures $\left(30^{\circ} \mathrm{C}, 40^{\circ} \mathrm{C}, 50^{\circ} \mathrm{C}\right)$ and $75 \% \mathrm{RH}$. The HPLC analysis showed that the average percentage of ITO $\mathrm{HCl}$ content ranged from $96.90 \%$ to $100.15 \%$.

Kinetic analysis of the data was carried out to determine the mechanism of drug degradation and $t_{90} \%$ (the time necessary to reach $90 \%$ of the labeled potency). Table 8 shows the values of the correlation coefficient of ITO $\mathrm{HCl}$ degradation in the selected formulae according to zero- and first-order reaction kinetics. The degradation of ITO $\mathrm{HCl}$ in the studied formulae followed first-order kinetics as indicated from the highest values of the correlation coefficient.

\section{Discussion}

The common way of controlling delivery is incorporating drug into a polymer. As the drug is freely water soluble, it requires careful selection of synthetic polymers such as Eudragit RSPM, Eudragit RS 100, ethylcellulose, and HPMC 15000.

Flow properties are very important for powder to be compressed into tablets. Materials that do not have good flow properties are difficult to compress into tablets and may lead to improper mixing of drug with other ingredients, which cause compression problems. The flow property of plain ITO $\mathrm{HCl}$ was improved by the addition of lubricants and directly compressing agent microcrystalline cellulose.

Floating results showed that as the concentration of polymer increased, the floating lag time, duration of floating, and matrix integrity increased by using sodium bicarbonate as a gas-generating agent for helping the tablets for floatation. ${ }^{24}$ Sodium bicarbonate generates $\mathrm{CO}_{2}$ in the dissolution medium $(0.1 \mathrm{~N} \mathrm{HCl})$; the gas liberated is trapped and protected within the gel formed by the hydration of the polymer, leading to decrease in the tablet density $<1 \mathrm{~g} / \mathrm{mL}$, and the tablet becomes buoyant. ${ }^{21}$ Moreover, the increased amount of sodium bicarbonate caused a large amount of effervescence, which in turn resulted in pore formation that led to rapid hydration of the polymer matrix and thereby to a rapid release of the drug.

Release profile indicated that increasing the polymer concentration from $34 \% \mathrm{w} / \mathrm{w}$ to $42 \% \mathrm{w} / \mathrm{w}$ has drastically retarded the release of ITO $\mathrm{HCl}$. A direct relationship was observed between concentration and cumulative percent drug release. The formulation containing 32\% w/w Eudragit RSPM $\left(\mathrm{F}_{8}\right)$ showed complete release of drug in 24 hours in a controlled manner as compared to HPMC 15000.

Combination of EC with Eudragit RSPM gave an excellent sustained release up to 24 hours. This is due to the increase in the gel strength of tablets; gel structure is formed 
around the tablet matrix, which considerably decreases the release rate of the drug since the drug has to diffuse through this gel barrier into the bulk phase.

These results are in accordance with those reported by Sanchez-Lafuente et al, ${ }^{25}$ who found that incorporation of Eudragit RSPM with hydrophobic ethylcellulose led to desirable modulation of drug release.

A kinetic study revealed that release of ITO from the prepared floating tablets showed diffusion-controlled release mechanism. This finding could be attributed to the formation of the gel structure by placing the tablet into the aqueous media.

The HPLC method used in the assay of ITO $\mathrm{HCl}$ is accurate, precise, specific, and a practical tool for the analysis of ITO $\mathrm{HCl}$ in plasma samples. The mean plasma concentration-time profiles reflect the sustaining of drug absorption from the tablet formula $\mathrm{F}_{10}$ compared with the immediate release tablets. The increase in $\mathrm{AUC}_{0-24 \text { hour }}$ and $F_{\mathrm{R} \%}$ of the prepared sustained-release formulations could be attributed to an increase in the residence time of the drug in the gastrointestinal tract. First, the prepared tablets were designed to release the drug very slowly along for 24 hours; accordingly, these systems should remain in the gastrointestinal tract until all drug cargo is released completely. An increase in the floating time leads to an increase in the residence time of the drug in the gastrointestinal tract, accordingly the greatest chance for drug release and absorption; hence, bioavailability is directly increased. The enhancement of the relative bioavailability of ITO from the oral route was a direct result of the elimination of the hepatic first-pass metabolism on oral delivery of the ITO.

The decrease in the in vitro release behavior of the prepared formula $\left(\mathrm{F}_{10}\right)$ could be attributed to the storage conditions $^{26}$ and the variations in the swelling behavior of the matrix polymer. ${ }^{27}$ This is in agreement with the results of Hosny, ${ }^{28}$ who reported a minor decrease in the dissolution of tablets after storage at room temperature. The samples evaluated after 1 month showed no change in the in vitro drug release pattern, indicating good similarity of dissolution profiles before and after stability studies.

\section{Conclusion}

Floating tablets of ITO $\mathrm{HCl}$ were successfully prepared in this study for improving the bioavailability of the drug. The floating technique used should also be suitable for sustaining the release of the drug. The prepared tablets could float on the dissolution medium surface and sustain release of ITO $\mathrm{HCl}$ over 24 hours. The tablets prepared with ethylcellulose and
Eudragit RSPM at 1:2 ratio showed optimum findings with respect to floating lag time, total floating duration, swelling ability, and sustained drug release profile.

In vivo evaluation of the prepared floating tablet proved that the bioavailability of the drug was increased 1.89-fold and plasma concentration of the drug after 24 hours was equal to that of the commercial tablet after 8 hours. Hence, the amount of the drug and number of administration per day were decreased. In line with recent recommendations to use the lowest amount of chemicals, the clinical study proved that more safety and fewer side effects could be predicted with this technique.

\section{Disclosure}

The authors report no conflicts of interest in this work.

\section{References}

1. Kim YS, Kim TH, Choi CS, et al. Effect of itopride, a new prokinetic, in patients with mild GERD: a pilot study. World J Gastroenterol. 2005; 11(27):4210-4214

2. Iwanaga Y, Miyashita N, Saito T, Morikawa K, Itoh Z. Gastroprokinetic effect of a new benzamide derivative itopride and its action mechanisms in conscious dogs. Jpn J Pharmacol. 1996;71(2):129-137.

3. Bose A, Wong TW, Singh N. Formulation development and optimization of sustained release matrix tablet of itopride $\mathrm{HCl}$ by response surface methodology and its evaluation of release kinetics. Saudi Pharm J. 2013;21(2):201-213.

4. Holtmann G, Talley NJ, Liebregts T, Adam B, Parow C. A placebocontrolled trial of itopride in functional dyspepsia. N Engl J Med. 2006; 354(8):832-840.

5. Satapathy T, Panda PK, Goyal AK, Rath G. Evaluation of anti-GERD activity of gastro retentive drug delivery system of itopride hydrochloride. Artif Cells Blood Substit Immobil Biotechnol. 2010;38(4): 200-207.

6. Moës AJ. Gastroretentive dosage forms. Crit Rev Ther Drug Carrier Syst. 1992;10(2):143-195.

7. Sheth PR, Tossounian J. The hydrodynamically balanced system (HBS ${ }^{\text {TM }): ~ a ~ n o v e l ~ d r u g ~ d e l i v e r y ~ s y s t e m ~ f o r ~ o r a l ~ u s e . ~ D r u g ~ D e v ~ I n d ~}$ Pharm. 1984;10(2):313-339.

8. Vo AQ, Feng X, Morott JT, et al. A novel floating controlled release drug delivery system prepared by hot-melt extrusion. Eur J Pharm Biopharm. 2016;98:108-121.

9. Kesarla RS, Vora PA, Sridhar BK, Patel G, Omri A. Formulation and evaluation of floating tablet of H2-receptor antagonist. Drug Dev Ind Pharm. 2015;41(9):1499-1511.

10. Baumgartner S, Kristl J, Vrecer F, Vodopivec P, Zorko B. Optimisation of floating matrix tablets and evaluation of their gastric residence time. Int J Pharm. 2000;195(1):125-135.

11. Reddy LH, Murthy RS. Floating dosage systems in drug delivery. Crit Rev Ther Drug Carrier Syst. 2002;19(6):553-585.

12. Li S, Lin S, Daggy BP, Mirchandani HL, Chien YW. Effect of HPMC and carbopol on the release and floating properties of gastric floating drug delivery system using factorial design. Int J Pharm. 2003; 253(1):13-22.

13. Sauzet C, Claeys-Bruno M, Nicolas M, Kister J, Piccerelle P, Prinderre P. An innovative floating gastro retentive dosage system: formulation and in vitro evaluation. Int J Pharm. 2009;378(1):23-29.

14. Streubel A, Siepmann J, Bodmeier R. Floating matrix tablets based on low density foam powder: effects of formulation and processing parameters on drug release. Eur J Pharm Sci. 2003;18(1):37-45. 
15. Lachman L, Lieberman HA, Kanig JL. The Theory and Practice of Industrial Pharmacy. Philadelphia, NY: Lea \& Febiger; 1986; Vol. 1.

16. Tadros MI. Controlled-release effervescent floating matrix tablets of ciprofloxacin hydrochloride: development, optimization and in vitro-in vivo evaluation in healthy human volunteers. Eur J Pharm Biopharm. 2010;74(2):332-339.

17. Srivastava AK, Wadhwa S, Ridhurkar D, Mishra B. Oral sustained delivery of atenolol from floating matrix tablets-formulation and in vitro evaluation. Drug Dev Ind Pharm. 2005;31(4-5):367-374.

18. Strübing S, Metz H, Mäder K. Characterization of poly (vinyl acetate) based floating matrix tablets. J Control Release. 2008;126(2): 149-155.

19. Wagner JG. Linear pharmacokinetic equations allowing direct calculation of many needed pharmacokinetic parameters from the coefficients and exponents of polyexponential equations which have been fitted to the data. J Pharmacokinet Biopharm. 1976;4(5): $443-467$

20. USP-23, N. United State Pharmacopoeia - XXIII National FormularyXXIII. Rockville, MD: United State Pharmacopoeia Convention, INC.; 1995:1625-1626.

21. Machida Y, Inouye K, Tokumura T, Iwata M, Nagai T. Preparation and evaluation of intragastric buoyant preparations. Drug Des Deliv. 1989; 4(2):155-161.
22. Choi BY, Park HJ, Hwang SJ, Park JB. Preparation of alginate beads for floating drug delivery system: effects of $\mathrm{CO}(2)$ gas-forming agents. Int J Pharm. 2002;239(1):81-91.

23. Gerogiannis VS, Rekkas DM, Dallas PP, Choulis NH. Floating and swelling characteristics of various excipients used in controlled release technology. Drug Dev Ind Pharm. 1993;19(9):1061-1081.

24. Chung M, Chia W, Wan W, Lin Y, Sung H. Controlled release of an anti-inflammatory drug using an ultrasensitive ROS-responsive gas-generating carrier for localized inflammation inhibition. J Am Chem Soc. 2016;137(39):12462-12465.

25. Sanchez-Lafuente C, Faucci MT, Fernández-Arévalo M, ÁlvarezFuentes J, Rabasco AM, Mura P. Development of sustained release matrix tablets of didanosine containing methacrylic and ethylcellulose polymers. Int J Pharm. 2002;234(1):213-221.

26. Horhota ST, Burgio J, Lonski L, Rhodes CT. Effect of storage at specified temperature and humidity on properties of three directly compressible tablet formulations. J Pharm Sci. 1976;65(12):1746-1749.

27. Goskonda VR, Reddy IK, Durrani MJ, Wilber W, Khan MA. Solid-state stability assessment of controlled release tablets containing carbopol 971P. J Control Release. 1998;54(1):87-93.

28. Hosny EA. Study of accelerated storage conditions affecting physical characteristics, in-vitro dissolution and stability of bioadhesive containing tablets. Boll Chim Farm. 1999;138(6):243-248.
Drug Design, Development and Therapy

\section{Publish your work in this journal}

Drug Design, Development and Therapy is an international, peerreviewed open-access journal that spans the spectrum of drug design and development through to clinical applications. Clinical outcomes, patient safety, and programs for the development and effective, safe, and sustained use of medicines are the features of the journal, which

\section{Dovepress}

has also been accepted for indexing on PubMed Central. The manuscript management system is completely online and includes a very quick and fair peer-review system, which is all easy to use. Visit http://www.dovepress.com/testimonials.php to read real quotes from published authors.

Submit your manuscript here: http://www.dovepress.com/drug-design-development-and-therapy-journal 